\title{
Economic Impacts of Using Switchgrass as a Feedstock for Ethanol Production: A Case Study Located in East Tennessee
}

\author{
Burton C. English, ${ }^{1}$ Tun-Hsiang Edward Yu, ${ }^{1}$ James A. Larson, \\ R. Jamey Menard, ${ }^{1}$ and Yuan Gao ${ }^{2}$ \\ ${ }^{1}$ Department of Agricultural \& Resource Economics, University of Tennessee, Knoxville, TN 37996-4518, USA \\ ${ }^{2}$ Emerging Market Division, Strategy, Policy and Review Department, International Monetary Fund, Washington, DC, USA
}

Correspondence should be addressed to Burton C. English; benglish@utk.edu

Received 8 September 2012; Revised 8 December 2012; Accepted 31 December 2012

Academic Editor: Silvia Secchi

Copyright ( $) 2013$ Burton C. English et al. This is an open access article distributed under the Creative Commons Attribution License, which permits unrestricted use, distribution, and reproduction in any medium, provided the original work is properly cited.

\begin{abstract}
One of the major motivations to establish a biobased energy sector in the United States is to promote economic development in the rural areas of the nation. This study estimated the economic impact of investing and operating a switchgrass-based ethanol plant in East Tennessee. Applying a spatially oriented mixed-integer mathematical programming model, we first determined the location of biorefinery, feedstock draw area, and the resources used in various feedstock supply systems by minimizing the total plant gate cost of feedstock. Based on the model output, an input-output model was utilized to determine the total economic impact, including direct, indirect, and induced effects of feedstock investment and annual production in the study region. Moreover, the economic impact of ethanol plant investment and annual conversion operation was analyzed. Results suggest that the total annual expenditures in an unprotected large round bale system generated a total $\$ 92.5$ million in economic output within the 13 counties of East Tennessee. In addition, an estimated \$234 million in overall economic output was generated through the operation of the biorefinery. This research showed that the least-cost configuration of the feedstock supply chain influenced the levels and types of economic impact of biorefinery.
\end{abstract}

\section{Introduction}

The Energy Independence and Security Act of 2007 mandates 136 billion liters of biofuels to be produced annually by the year 2022 with 61 billion liters coming from cellulosic sources [1]. A major source of feedstock required to meet the mandate is lignocellulosic biomass (LCB). As indicated in two recent studies, the United States is capable of producing over a billion tons of LCB annually $[2,3]$. Produced from dedicated energy crops, crop and forest residues, and municipal solid waste streams, LCB can play a significant role in the production of biobased fuels, power, and products in the United States. The Roadmap for Bioenergy and Biobased Products in the United States [4] indicates that the development of a biobased industrial sector using LCB feedstock in the United States can reduce dependence on imported petroleum, add to the diversity of energy sources, enhance energy security, improve the balance of trade, reduce carbon emissions, increase carbon sequestration, and stimulate economic growth in rural areas. This research evaluates the potential economic impacts of locating a switchgrass-toethanol biorefinery in rural East Tennessee, USA.

Switchgrass is a strong candidate as a dedicated energy crop for biofuel production because it is a high yielding, herbaceous perennial grass native to the United States [5]. As a native species, switchgrass is resistant to many diseases and pests and is well suited to the climate and soils of a large portion of the United States [6]. Switchgrass was 
chosen in 1991 as the model herbaceous bioenergy crop by the US Department of Energy for the southeastern US after years of research by the Bioenergy Feedstock Development Program at Oak Ridge National Laboratory (ORNL) [7]. Switchgrass has reliable productivity on poorer soils, lower demand for fertilizer than row crops such as corn, high water use efficiency, and a high tolerance to a wide range of environmental conditions [8]. Thus, switchgrass production may be ideal on the marginal pasturelands and croplands that are subject to soil erosion. These marginal lands are commonly found in the semihumid and humid environments of the southeastern U.S. including the State of Tennessee.

In Tennessee, switchgrass will likely be harvested once a year after senesce to maximize LCB yields and minimize the removal of plant nutrients [6]. It can be harvested and handled using conventional hay equipment but one of the issues with this system is the relatively low density of the feedstock when it is packaged this way. Thus, large-scale storage space, on-farm or at satellite sites, will likely be required to store switchgrass [9]. For example, maintaining a one-year supply of switchgrass feedstock for a commercialscale $189,271 \mathrm{kl} \mathrm{year}^{-1}$ ethanol biorefinery would require a $9.75 \mathrm{~m}$ high stack of $1.2 \mathrm{~m} \times 1.2 \mathrm{~m} \times 2.4 \mathrm{~m}$ rectangular bales covering more than 40 ha of land [10]. Therefore, storage can potentially be an important factor in determining total feedstock costs at the biorefinery plant gate. Also, the potential for dry matter losses during storage of feedstock that is packaged using conventional hay equipment, particularly in the semihumid and humid climate of the southeastern U.S., may reduce the quantity and quality of biomass in switchgrass and potentially increases the production costs of biofuels [11]. Furthermore, transporting switchgrass feedstock from the supply areas to the biorefinery is expected to generate significant truck flows due to low feedstock density. The low density of switchgrass feedstock and the extensive land base requirements to grow the feedstock indicate that the likely locations of biorefineries will be in rural areas close to feedstock production.

The State of Tennessee committed \$70 million in 2007 to establish the Tennessee Biofuels Initiative for developing a farm-to-fuel business plan for a biofuel industry in Tennessee [10]. More than 2,000 ha of switchgrass have been established as part of the initiative. In addition, a pilot LCB-based ethanol plant with a capacity of $946 \mathrm{kl} \mathrm{year}^{-1}$ has been operated in East Tennessee at Vonore, TN, USA, by DuPont Cellulosic Ethanol and Genera Energy LLC (a for profit company formed by The University of Tennessee under the initiative) since January 2010. Depending on market conditions and the success of the pilot facility in Vonore, a commercial biorefinery may be developed and switchgrass planted area in East Tennessee would be expanded to supply the facility [10].

In view of the importance placed on the development of an LCB-based biofuel industry in Tennessee, this study aims (1) to evaluate the least-cost production, harvest, storage, and transportation activities for a potential switchgrass feedstock supply chain for a commercial-sized biorefinery located in a 13-county East Tennessee region related to the pilot facility in
Vonore and (2) to analyze the impacts of increased economic activity due to feedstock supply chain and biorefinery operations on the economy of the region.

\section{Literature Review}

Estimating the local economic impacts of a potential biorefinery is an important step in the overall evaluation of the economic, environmental, and social impacts of biofuels production on a rural community [4]. Input-output (IO) analysis has been the most commonly used method for determining changes in output, employment, and value added from new economic activities such as biofuels production [12]. I-O analysis was first developed by Leontief in the 1930s [12]. Several studies have used I-O analysis to evaluate the macroeconomic effects of ethanol production from corn, soybean, wheat, and barley for Canada and the United States [13-16]. In addition, the potential economic impacts of replacing a portion of fossil-based fuels in the United States with advanced biofuels derived from multiple feedstocks including LCB have been evaluated using I-O analysis [3, 17]. In addition, studies evaluating the economic impacts of biofuels production at the state-level also have been completed (e.g., [18-20]). The aforementioned studies provided valuable insights into the potentially positive impacts of biofuels production at the macroeconomic level but do not give an indication of the potential local economic impacts of an individual biofuels conversion facility.

Leistritz and Hodur [21] reviewed I-O analysis studies at the biorefinery level in North Dakota to compare the potential economic impacts of wheat-straw- and corn-based ethanol biorefineries. They found that the wheat-straw-based biorefinery had a larger overall economic impact than the corn-based facility. This is because corn has an existing market and the payments for wheat straw represent new income to farmers and others in the feedstock supply chain. Lazarus et al. [12] also using I-O analysis found that the construction of a conversion facility in Minnesota using a short-rotation woody crop as the feedstock had potentially large positive economic impacts. Their result was because of the low opportunity cost of beef cattle production that LCB production displaced. The conversion facility did not substantially change overall employment numbers but enhanced salaries and business tax collections resulted in a larger value added. Bailey et al. [22] applied an I-O model to evaluate the economic impacts of establishing a set of six biorefineries using LCB feedstocks in Alabama and the impact of locating a wood base conversion facility in a region with persistent rural poverty in west Alabama. Results in the Lazarus et al. and Bailey et al. studies suggested that the establishment of an LCB-based biofuel industry could contribute to economic development and job growth, especially in the logging sector and in rural regions. Aksoy et al. [23] also evaluated the potential economic impacts of establishing biorefinery using four different technologies to convert woody biomass and mill waste to liquid fuel in Alabama. They determined the location of each type of biorefinery technology by minimizing transportation cost of hauling feedstock to the biorefinery. 
TABLE 1: Definition of variables and parameters for BeSTA Model.

\begin{tabular}{|c|c|c|}
\hline $\begin{array}{l}\text { Variables/ } \\
\text { parameters/ } \\
\text { subscripts }\end{array}$ & Unit & Definition \\
\hline \multicolumn{3}{|l|}{ Variables } \\
\hline A & $\mathrm{Ha}$ & Switchgrass produced annually \\
\hline $\mathrm{AH}$ & $\mathrm{Ha}$ & $\begin{array}{l}\text { Switchgrass harvested monthly from } \\
\text { November to February }\end{array}$ \\
\hline $\mathrm{XC}$ & $\mathrm{Mg}$ & Switchgrass produced annually \\
\hline $\mathrm{XH}$ & $\mathrm{Mg}$ & $\begin{array}{l}\text { Switchgrass harvested monthly from } \\
\text { November to February }\end{array}$ \\
\hline XTN & $\mathrm{Mg}$ & $\begin{array}{l}\text { Switchgrass transported directly to the } \\
\text { biorefinery after harvest from } \\
\text { November to February }\end{array}$ \\
\hline NXS & $\mathrm{Mg}$ & $\begin{array}{l}\text { Tons of switchgrass newly stored } \\
\text { monthly from November to February }\end{array}$ \\
\hline $\mathrm{XS}$ & $\mathrm{Mg}$ & $\begin{array}{l}\text { Switchgrass stored monthly from } \\
\text { November to October }\end{array}$ \\
\hline XTO & $\mathrm{Mg}$ & $\begin{array}{l}\text { switchgrass transported from storage } \\
\text { to the biorefinery from March to } \\
\text { October }\end{array}$ \\
\hline Numb & & Number of equipment used in harvest \\
\hline Q & $\mathrm{Kl}$ & $\begin{array}{l}\text { Quantity of ethanol produced in each } \\
\text { month }\end{array}$ \\
\hline \multicolumn{3}{|l|}{ Parameters } \\
\hline BEP & $\$ /$ ha & $\begin{array}{l}\text { Breakeven price of planting } \\
\text { switchgrass as an alternative to } \\
\text { traditional crops }\end{array}$ \\
\hline$\Gamma$ & $\$ /$ ton & Storage cost per ton \\
\hline$\Theta$ & $\$ /$ ton & $\begin{array}{l}\text { Transportation cost per ton from field } \\
\text { to the biorefinery }\end{array}$ \\
\hline $\mathrm{Aa}$ & ha & $\begin{array}{l}\text { Cropland available in each hexagon for } \\
\text { each crop }\end{array}$ \\
\hline$Y$ & $\mathrm{Mg} / \mathrm{ha}$ & Switchgrass yield \\
\hline $\mathrm{DML}_{\text {stor }}$ & $\%$ & Dry matter loss during storage \\
\hline $\mathrm{DML}_{\text {trans }}$ & $\%$ & Dry matter loss during transportation \\
\hline Mtb & hour/ha & $\begin{array}{l}\text { Machine time per ha for each } \\
\text { machinery }\end{array}$ \\
\hline Avehour & hour & $\begin{array}{l}\text { Available average working hours of } \\
\text { machinery in each month }\end{array}$ \\
\hline$\Lambda$ & $\mathrm{kl} / \mathrm{Mg}$ & $\begin{array}{l}\text { Conversion rate of switchgrass to } \\
\text { ethanol }\end{array}$ \\
\hline \multicolumn{3}{|l|}{ Subscripts } \\
\hline$M$ & & Month \\
\hline$I$ & & Locations of biomass production field \\
\hline$Z$ & & Location of the biorefinery \\
\hline$P$ & & Crop type \\
\hline$B$ & & $\begin{array}{l}\text { Harvest method (square baler, round } \\
\text { baler) }\end{array}$ \\
\hline$T$ & & Storage protection method \\
\hline
\end{tabular}

differences in economic impacts among the four biorefinery technologies.

The aforementioned I-O analysis studies used very simple assumptions about the structure of the feedstock supply chain to conduct their research. These assumptions may not be appropriate for a dedicated energy crop such as switchgrass which may compete with both livestock and row-crop activities. Also, those regional and state summaries have much less robust feedstock, transport, and operational job impacts on a million gallon of ethanol produced basis than the present study. This research adds to the developing literature on the economic impacts of a local biofuels conversion facility by using a spatially oriented feedstock supply chain model to model least-cost production, harvest, storage, and transportation activities to provide coefficients for the $\mathrm{I}-\mathrm{O}$ analysis. Factors considered in the cost minimization analysis were available field days during harvest, large round bale and large rectangular bale harvest and storage methods, DM losses during storage, farm and biorefinery constraints, available land resources in the region, opportunity costs on converting agricultural land to switchgrass production, the real road network, and available industrial parks in the region for placing a conversion facility.

\section{Methods and Data}

3.1. Determining the Total Plant Gate Costs of Switchgrass. The Bio-energy Site and Technology Assessment (BeSTA) model was used to estimate where and when feedstock procurement would occur for a biorefinery facility. BeSTA is a spatiallyoriented, mixed-integer mathematical programming model that models LCB feedstock supply chain activities at the biorefinery level [24]. Remote-sensing data from a geographical information system resource model, BioFLAME [25], was used as input in the BeSTA model to determine the LCB feedstock draw area; biorefinery location; and the monthly harvest, delivery, and storage volume of feedstock to meet the demand of feedstock from biorefinery at the least total plant gate cost. Data used by BeSTA from BioFLAME included crop yields and soil types at the subcounty level and the real road network. The model structure is as follows (the definitions of variables and parameters can be found in Table 1):

Min. TLC

$$
=\sum_{i} \sum_{p} \sum_{b}\left(\mathrm{BEP}_{i p b} \times \mathrm{XC}_{i p b}\right)
$$

(production and harvest cost)

$$
\begin{aligned}
& +\sum_{m} \sum_{i} \sum_{p} \sum_{b} \sum_{t} \gamma_{i b t} \times \mathrm{NXS}_{\text {mipbt }} \quad \text { (storage cost) } \\
& +\sum_{i} \sum_{b} \theta_{i b} \times \frac{\left(\sum_{m} \sum_{p} \mathrm{XTN}_{m i p b}+\sum_{m} \sum_{p} \sum_{t} \mathrm{XTO}_{m i p b t}\right)}{1-\mathrm{DML}_{\text {trans }}}
\end{aligned}
$$

(transportation cost)
The economic impacts of the four biorefinery technologies were then compared using I-O analysis. Their study found no 
s.t. $\quad \sum_{b} A_{i p b} \leq a a_{i p}, \quad \forall i, p$

(acreage constraint for production)

$$
\mathrm{XC}_{i p b} \leq y_{i b} \times A_{i p b}, \quad \forall i, p, b
$$

(yield constraint for production)

$\mathrm{XH}_{\text {mipb }}=0, \quad$ March $\leq m \leq$ Oct $\forall m, i, p, b$

(constraint on harvest month)

$\mathrm{Numb}_{m b} \times$ avehour $_{m}-\sum_{i} \sum_{p}\left(m t b_{i b} \times \mathrm{AH}_{m i p b}\right)$

$\geq 0, \quad \forall m, b$

(constraint on harvest machine working hours)

$$
\mathrm{XH}_{\text {mipb }}-\frac{\sum_{j} \mathrm{XTN}_{\text {mipb }}}{1-\mathrm{DML}_{\text {trans }}} \geq 0, \quad \forall m, i, p, b
$$

(harvest and direct shipment balance)

$\mathrm{XH}_{\text {mipb }}-\sum_{t} \mathrm{NXS}_{\text {mipbt }} \geq 0, \quad$ March $\leq m \leq$ Oct $\forall m, i, p, b$

(harvest and storage balance)

$\mathrm{XS}_{\text {mipbt }}-\frac{\mathrm{XTO}_{(m+1) i p b t}}{1-\mathrm{DML}_{\text {trans }}} \geq 0, \quad \forall m, i, p, b, t$

(storage and shipment balance)

$$
\begin{gathered}
\lambda\left(\sum_{i} \sum_{p} \sum_{b} \mathrm{XTN}_{\text {mipb }}+\sum_{i} \sum_{p} \sum_{b} \sum_{t} \mathrm{XTO}_{\text {mipbt }}\right)-\mathrm{Q}_{m} \\
=0, \quad \forall m \quad \text { (ethanol production) }
\end{gathered}
$$$$
\mathrm{XS}_{(m+1) i p b t}=\left(1-\mathrm{DML} \_ \text {stor }_{m b t}\right) \times \mathrm{XS}_{\text {mipbt }}
$$$$
+\mathrm{NXS}_{(m+1) i p b t}, \text { Nov } \leq m \leq \text { Feb } \forall m, i, p, b, t
$$

(cumulative storage balance during harvest season)

$$
\begin{array}{r}
\mathrm{XS}_{(m+1) i p b t}=\left(1-\mathrm{DML} \_s t o r_{m b t}\right) \times \mathrm{XS}_{\text {mipbt }}-\frac{\mathrm{XTO}_{(m+1) i p b t}}{1-\mathrm{DML}_{-} \text {tran }}, \\
\mathrm{March} \leq m \leq \mathrm{Oct} \forall m, i, p, b, t
\end{array}
$$

(cumulative storage balance during off-harvest season).

The objective function (1) minimizes the total plant gate cost (TLC) including costs of production, harvest, storage, and transport adjusted for dry matter losses at each stage after production, subject to constraints on feedstock production, feedstock demand, and various logistics and harvest conditions. Production cost for switchgrass includes the foregone net return (opportunity cost) for the crop grown for a given land resource unit in the model. The objective function is subject to eleven different constraint types. Equations (2) and (3) restrict available land area and yield for LCB feedstock production in each production area. Equations (4) and (5) constrain the harvest month and the harvest machine hours per month during harvest season, respectively. Equation (6) requires feedstock delivered each month to not exceed harvested feedstock in each month after adjusting for transportation dry matter losses. Similarly, the amount of feedstock put into storage should be less than feedstock harvested each month (7). Equation (8) assures that feedstock delivered from storage cannot exceed available stocks in storage in each month. In addition, feedstock delivered to the biorefinery in each month must meet the demand for biofuel production by the biorefinery (9). Finally, (10) and (11) maintain the balance of cumulative storage of switchgrass after taking into account dry matter loss during both the harvest and off-harvest seasons. All parameters and variables in the model are nonnegative.

While numerous methods exist to harvest, store, and transport switchgrass, two potential switchgrass feedstock harvest and storage systems using conventional hay harvest technologies were evaluated, (1) large square bales and (2) large round bales, because of the availability of equipment in study area. Transportation of large square bales is more efficient given that the flatbed truck used to haul the material can be loaded to higher weights [9]. However, large round bales shed moisture better during outdoor storage, thus reducing dry matter losses [11]. Machinery operations for the two harvest and logistics systems are similar [9]. Switchgrass feedstocks are assumed to be mowed, raked, and baled in each potential supply area in the model. A portion of the harvested feedstock is loaded onto a semitruck trailer and transported to the biorefinery directly for biofuel production per month during the harvest window. The remaining switchgrass bales are stored on the edge of the field either without protection or with the protection of plastic tarp and wooden pallets. When the harvest season is completed, the stored bales are hauled to the biorefinery by a semi-truck trailer for biofuel production each month during the off-harvest season. Dry matter loss during storage is a significant issue for those bales, particularly large square bales. Cumulative dry matter losses for each bale storage method were modeled using estimated relationships from a switchgrass bale storage study [11]. This analysis will focus on four different logistic systems.

(1) Round Top Protected-this system produces a large round bale which is stored on the ground and protected with a tarp.

(2) Round Unprotected-this system produces a large round bale which is stored without any protection so storage costs, not including dry matter loss, are zero.

(3) Square Top and Bottom Protected-this system produces a large $1.2 \mathrm{~m} \times 1.2 \mathrm{~m} \times 2.4 \mathrm{~m}$ bale which is stored on pallets and with a tarp. 


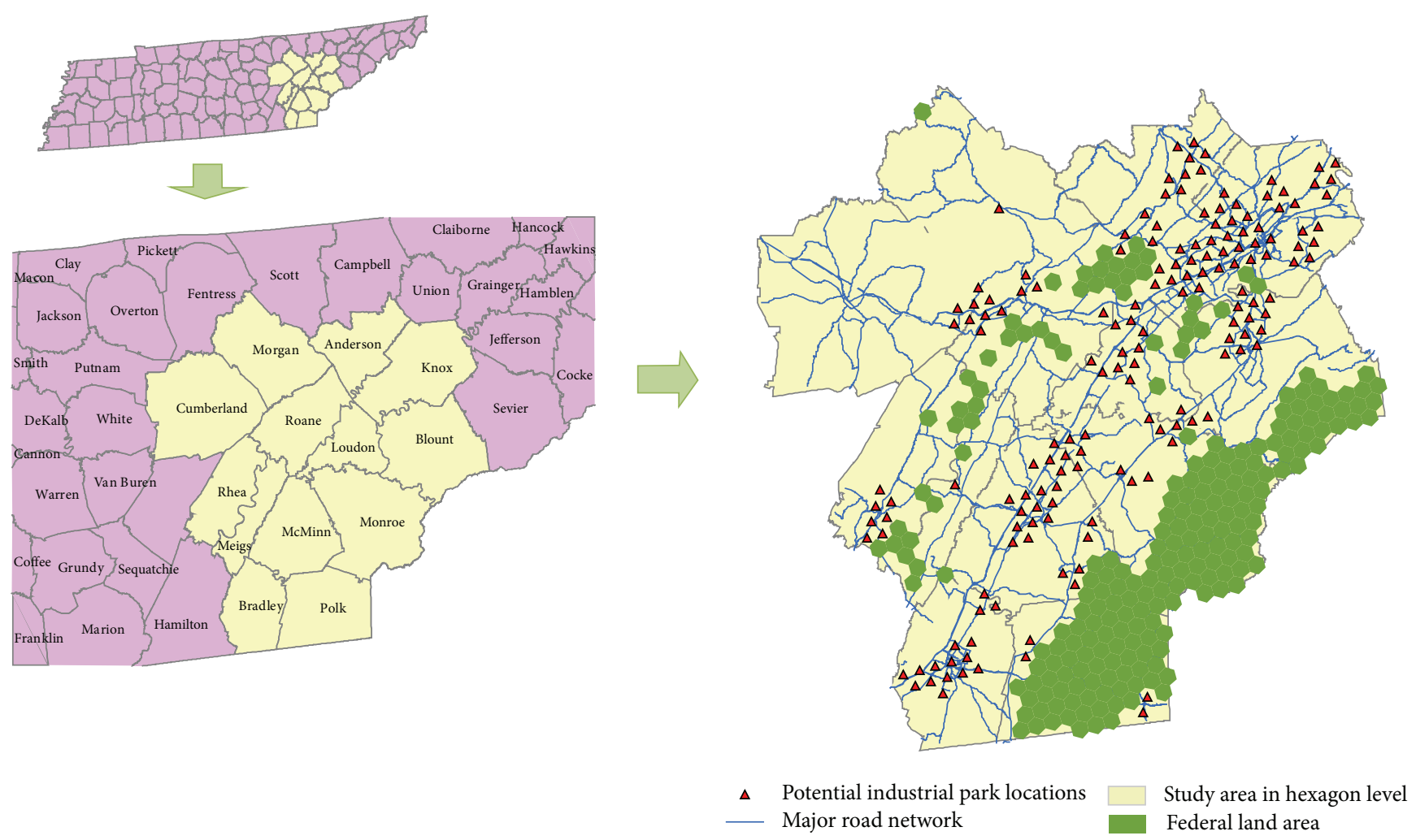

FIGURE 1: Potential area of feedstock production and the biorefinery in study.

(4) Square Top Unprotected-this system produces a large $1.2 \mathrm{~m} \times 1.2 \mathrm{~m} \times 2.4 \mathrm{~m}$ bale which is stored on pallets without a tarp.

The study area for the analysis included 13 counties in East Tennessee (Anderson, Blount, Bradley, Cumberland, Knox, Loudon, McMinn, Meigs, Monroe, Morgan, Polk, Rhea, and Roane) that are within $80 \mathrm{~km}$ of the pilot biorefinery in Vonore, TN, USA, Switchgrass feedstock supply areas and the potential location of a commercial-scale biorefinery were determined within the 13 counties using the BeSTA model. The study region was divided into 1,144 land resource units (13- $\mathrm{km}^{2}$ hexagons) to better calculate the distance between switchgrass supply areas and the potential biorefinery location (Figure 1). Federal land in the 13-county region was excluded from the potential supply area. Each hexagon was considered as a separate supply region. Potential locations for the new commercial-scale biorefinery included 163 industrial park sites as represented in Figure 1. Therefore, site preparation costs and utility and water infrastructure are available to the facility with no additional investment.

The operation of the commercial-scale biorefinery was assumed to be year-round with an annual production capacity of $189,271 \mathrm{kl}^{\text {of ethanol year }}{ }^{-1}$ [27]. Assuming a conversion

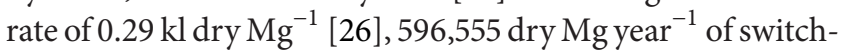
grass feedstock was required to meet the biofuel production of the biorefinery. Switchgrass was assumed to be harvested once per year from November through February. Based on the historical weather data, the number of dry days for harvest operations during the four months was 53 days or a total of 325 hours of machine operation time [9].

3.2. Estimating the Economic Impacts within the Study Region and within the State. The economic impact of changes in economic activity resulting from the establishment of a $189,271 \mathrm{kl}$ facility is estimated for the 13-county region using 2010 IMPLAN data [28]. Within the input-output framework, each industrial sector interacts with other sectors by selling its product/output to others and purchasing materials/inputs from the other sectors. The interdependence among industries or sectors can be traced to evaluate the multiplying impact of an expenditure or investment in the economy. The overall impact can be categorized into three components: direct impacts, indirect impacts, and induced impacts. Direct impacts result from expenditures/transactions in the economy. Indirect impacts happen because products/services that are purchased require inputs/services from other sectors, and similarly those inputs/services will be linked to their providers in the upper stream. With those multiplying transactions among various sectors, the salaries/compensation of the household in the economy will likely be affected, hence creating induced impacts on consumption in the economy.

In this study, two different types of impacts are traced through the economy. The first impact is a result of the investments required to establish the biorefinery and to establish the perennial switchgrass feedstock draw area. The second impact arises from annual operating transactions. Investment impacts occur once while operating impacts 
recur annually. There are several components within each impact type. For example, there are two primary investment impacts: one as a result of biorefinery construction and the other as a result of the one-time establishment of perennial switchgrass. There may be other investments outlays required such as additional balers and trucks, but these are not included in our investment impact analysis. In the annual operating impact analysis, the annual maintenance of the perennial switchgrass stand (i.e., fertilization), harvest, storage, and transportation of switchgrass to the plant gate are included along with biorefinery operations. The other factors considered in the I-O analysis are (1) losses to the region because of land use changes from growing switchgrass rather than producing traditional agricultural commodities and (2) changes in employment from changes in economic activity from switchgrass and biofuels production.

For the I-O analysis, activities related to the one time establishment of the perennial switchgrass are investment and the annual activities related to annual switchgrass feedstock supply were determined using the BeSTA model. Biorefinery construction, an investment, and annual biorefinery operations were from an economic engineering technical analysis by the National Renewable Energy Lab (NREL) [29]. The accompanying economic impact was estimated using the Tennessee Agri-Industry Model (TN-AIM) [30]. A version of the TN-AIM model was developed to focus on the 440 industry sectors in the 13-county region based on the Impact Analysis for Planning (IMPLAN) model and its databases [28]. IMPLAN creates a set of economic/social accounts and multipliers that balances market-based transactions and nonmarket financial flows based on a regional social accounting matrix (SAM). Output from the model includes measures of several economic indicators including total industry output, employment, and value-added in the Tennessee economy. Total industry output represents the value of production by industry per year, while total value-added covers the income to workers from employers, self-employed income; interest, rent, royalties, dividends, and profits; and excise and sales taxes paid by individuals to business. For each of those economic indicators, an SAM multiplier, generated by dividing the overall impact (direct + indirect + induced impacts) by the direct impact, was used to represent the extension of the direct impact on the economy.

The NREL technical report [29] was used as a guide to estimate the economic impacts of the $189,271 \mathrm{kl} \mathrm{year}^{-1}$ LCB ethanol facility. The report has detailed engineering economics for both capital investment and annual operating costs in $2007 \$$ for a $303,969 \mathrm{kl} \mathrm{year}^{-1}$ nameplate LCB ethanol facility. Based on a capacity factor of $76 \%$, annual ethanol production is $231,016 \mathrm{kl}_{\text {year }}{ }^{-1}$. To derive the engineering economic expenditure information for the $189,271 \mathrm{kl} \mathrm{year}^{-1}$ facility used in this analysis, expenditures were scaled by 0.82 . Detailed equipment expenditures for the main process areas to operate the facility (i.e., feed handling; pretreatment and conditioning; enzymatic hydrolysis and fermentation; cellulose enzyme production; product recovery; wastewater treatment; storage; combustor, boiler, and turbogenerator; and utilities) were assigned to the appropriate industries in
IMPLAN. Based on scaling methodology used and inflating 2007 expenditures to 2010, the year of the most recent data available in IMPLAN, total capital expenditures were estimated at \$391.0 million. For construction, industries with expenditures not in the 13-county study area are metal can, box, and other metal container (light gauge) manufacturing (this is for hoppers and bins); turbines and turbine generator set units manufacturing; and air and gas compressor manufacturing. Combined, this totals $\$ 17$ million in leakage from the region. (Leakages to the local economy that occurred in the analysis were defined by regional purchase coefficients. No adjustments were made to the regional purchase coefficients in the 13-county I-O analysis. However, there were several industries that do not exist within the 13county region from which purchases were made in the I$\mathrm{O}$ analysis. For those imports, an impact was not recorded. In the construction phase, work crews may be "imported" into the region to build a facility with their corresponding income spending occurring in their home region. This would be considered a leakage that is not accounted for in the analysis.) Likewise, for operating, they are phosphatic fertilizer manufacturing; lime and gypsum product manufacturing; metal can, box, and other metal container (light gauge) manufacturing, and turbines and turbine generator set units manufacturing. Combined, this totals to over $\$ 7$ million for operating (leakage). The 13-county region was directly impacted by these values (roughly 20 events for construction and 15 events for operating in the IMPLAN model).

Annual operating impact expenditures were derived in a similar manner. Boiler chemicals, cooling tower chemicals, make-up water, lime, sulfuric acid, ammonia, and other chemicals necessary for producing ethanol annually were all assigned to the appropriate IMPLAN industries. These values summed to $\$ 31.5$ million and do not include feedstock or transportation costs. To capture the annual operating impacts, two new industries were created in the 13-county IMPLAN model. One industry was created for converting the ethanol and another was created for the production of switchgrass, the feedstock used to produce ethanol. Next, new production function industry information was created for the two new industries created. Other adjustments, where appropriate, included commodity byproduct production for the ethanol conversion facility and trade flow adjustments. Finally, these two new industries were impacted by each of their respective total industry outputs. The estimates for switchgrass establishment, construction of the biorefinery, annually operating the biorefinery, and the maintenance, and harvest of switchgrass are presented in Tables 2 and 3. Switchgrass production, harvest, storage, and transportation costs are derived from UT Extension budgets [31] and Larson et al. [9]. The production costs of other crops were from The Policy Analysis System (POLYSYS) agricultural policy simulation model and indexed to 2010 dollars [3].

\section{Results}

4.1. Economic Analysis of the Harvest/Storage Systems. For the 13-county study area, the BeSTA model determined 
TABLE 2: Cost of switchgrass and the assigned IMPLAN sector affected.

\begin{tabular}{|c|c|c|c|c|c|c|c|}
\hline $\begin{array}{l}\text { IMPLAN } \\
\text { sector }\end{array}$ & IMPLAN sector description & Input category & Description & Unit & Quantity & Price & Total \\
\hline \multicolumn{8}{|c|}{ Establishment } \\
\hline 10 & All other crop farming & Seed & Pure live seed & $\mathrm{lb}$ & 6 & $\$ 8.00$ & $\$ 48.00$ \\
\hline 19 & Fertilizer manufacturing & Fertilizer & $\mathrm{P}_{2} \mathrm{O}_{5}$ & $\mathrm{lb}$ & 40 & $\$ 0.80$ & $\$ 32.00$ \\
\hline 19 & Fertilizer manufacturing & Fertilizer & $\mathrm{K}_{2} \mathrm{O}$ & $\mathrm{lb}$ & 80 & $\$ 0.75$ & $\$ 60.00$ \\
\hline 131 & $\begin{array}{l}\text { Pesticide and other agricultural chemical } \\
\text { manufacturing }\end{array}$ & Weed control & Glyphosate & qt & 1 & $\$ 7.87$ & $\$ 7.87$ \\
\hline 131 & $\begin{array}{l}\text { Pesticide and other agricultural chemical } \\
\text { manufacturing }\end{array}$ & Weed control & Glyphosate & qt & 1.5 & $\$ 7.87$ & $\$ 11.81$ \\
\hline 131 & $\begin{array}{l}\text { Pesticide and other agricultural chemical } \\
\text { manufacturing }\end{array}$ & Weed control & Broadleaf herbicide & $\mathrm{pt}$ & 2 & $\$ 2.50$ & $\$ 5.00$ \\
\hline 131 & $\begin{array}{l}\text { Pesticide and other agricultural chemical } \\
\text { manufacturing }\end{array}$ & Weed control & Grass herbicide & Acre & 1 & $\$ 8.00$ & $\$ 8.00$ \\
\hline 131 & $\begin{array}{l}\text { Pesticide and other agricultural chemical } \\
\text { manufacturing }\end{array}$ & Weed control & Grass herbicide & Acre & 1 & $\$ 8.00$ & $\$ 8.00$ \\
\hline 417 & $\begin{array}{l}\text { Commercial and industrial machinery } \\
\text { and equipment repair and maintenance }\end{array}$ & $\begin{array}{l}\text { Machinery } \\
\text { repair }\end{array}$ & & Acre & 1 & $\$ 8.07$ & $\$ 8.07$ \\
\hline 326 & Retail stores, gasoline stations & Machinery fuel & Diesel at $\$ 2.50 /$ gallon & Acre & 1 & $\$ 11.31$ & $\$ 11.31$ \\
\hline 354 & $\begin{array}{l}\text { Monetary authorities and depository } \\
\text { credit intermediation }\end{array}$ & $\begin{array}{l}\text { Operating } \\
\text { capital }\end{array}$ & 6 months & Acre & $\$ 152.05$ & $8.00 \%$ & $\$ 6.08$ \\
\hline 368 & $\begin{array}{l}\text { Accounting, tax preparation, } \\
\text { bookkeeping, and payroll services }\end{array}$ & $\begin{array}{l}\text { Machinery } \\
\text { expenses }\end{array}$ & Depreciation & Acre & 1 & $\$ 8.70$ & $\$ 8.70$ \\
\hline 354 & $\begin{array}{l}\text { Monetary authorities and depository } \\
\text { credit intermediation }\end{array}$ & Interest expense & Machinery and equip & Acre & 1 & $\$ 6.09$ & $\$ 6.09$ \\
\hline 19 & $\begin{array}{l}\text { Support activities for agriculture and } \\
\text { forestry }\end{array}$ & Labor & Labor & $\mathrm{Hr}$ & 0.68 & $\$ 9.75$ & $\$ 6.63$ \\
\hline \multicolumn{8}{|c|}{ Annual Production Cost (years 2-10) } \\
\hline 19 & Fertilizer manufacturing & Fertilizer & Nitrogen & $\mathrm{lb}$ & 60 & $\$ 0.76$ & $\$ 45.60$ \\
\hline 19 & Fertilizer manufacturing & Fertilizer & $\mathrm{P}_{2} \mathrm{O}_{5}$ & $\mathrm{lb}$ & 40 & $\$ 0.80$ & $\$ 32.00$ \\
\hline 19 & Fertilizer manufacturing & Fertilizer & $\mathrm{K}_{2} \mathrm{O}$ & $\mathrm{lb}$ & 80 & $\$ 0.75$ & $\$ 60.00$ \\
\hline 203 & $\begin{array}{l}\text { Farm machinery and equipment } \\
\text { manufacturing }\end{array}$ & Triple tie & Twine, 1500 lb. bale & Bale & 5.9 & $\$ 1.75$ & $\$ 10.33$ \\
\hline 131 & $\begin{array}{l}\text { Pesticide and other agricultural chemical } \\
\text { manufacturing }\end{array}$ & Weed control & Broadleaf herbicide & pt & 2 & $\$ 2.50$ & $\$ 5.00$ \\
\hline 131 & $\begin{array}{l}\text { Pesticide and other agricultural chemical } \\
\text { manufacturing }\end{array}$ & Weed control & Grass herbicide & Acre & 1 & $\$ 8.00$ & $\$ 8.00$ \\
\hline 417 & $\begin{array}{l}\text { Commercial and industrial machinery } \\
\text { and equipment repair and maintenance }\end{array}$ & $\begin{array}{l}\text { Machinery } \\
\text { repair }\end{array}$ & & Acre & 1 & $\$ 30.51$ & $\$ 30.51$ \\
\hline 326 & Retail stores, gasoline stations & Machinery fuel & Diesel at $\$ 2.50 /$ gallon & Acre & 1 & $\$ 42.56$ & $\$ 42.56$ \\
\hline 354 & $\begin{array}{l}\text { Monetary authorities and depository } \\
\text { credit intermediation }\end{array}$ & $\begin{array}{l}\text { Operating } \\
\text { capital }\end{array}$ & 6 months & Acre & 233.99 & $8.00 \%$ & $\$ 9.36$ \\
\hline 368 & $\begin{array}{l}\text { Accounting, tax preparation, } \\
\text { bookkeeping, and payroll services }\end{array}$ & $\begin{array}{l}\text { Machinery } \\
\text { expenses }\end{array}$ & Depreciation & Acre & 1 & $\$ 34.21$ & $\$ 34.21$ \\
\hline 354 & $\begin{array}{l}\text { Monetary authorities and depository } \\
\text { credit intermediation }\end{array}$ & Interest expense & Machinery and equip & Acre & 1 & $\$ 18.12$ & $\$ 18.12$ \\
\hline 19 & $\begin{array}{l}\text { Support activities for agriculture and } \\
\text { forestry }\end{array}$ & Labor & Labor & $\mathrm{Hr}$ & 2.54 & $\$ 9.75$ & $\$ 24.77$ \\
\hline
\end{tabular}

Source: [26].

the optimal biorefinery location that minimized feedstock cost given other siting criteria (Figures 2 and 3). The same industrial park site was chosen for all four bale harvest and storage systems and was near Interstate 75 in northwest Monroe County. Switchgrass feedstock was supplied from all 13 counties in the study area although the major supply areas were located in the southeast portion of the study region. The feedstock draw area extends primarily along the Interstate 75 corridor. Density of switchgrass production in some land resource units in the study region as indicated 
TABLE 3: Investment and annual operating transactions of biorefinery indexed to 2010 using IMPLAN inflators and the assigned IMPLAN sector.

\begin{tabular}{|c|c|c|}
\hline IMPLAN sector & IMPLAN sector description & 2010 transactions \\
\hline \multicolumn{3}{|c|}{ Investment } \\
\hline 36 & $\begin{array}{l}\text { Construction of other new nonresidential structures (dome reclaim system, } \\
\text { concrete feedstock storage dome, anaerobic basin, warehouse, site } \\
\text { development, piping, field expenses) }\end{array}$ & $\$ 69,179,498$ \\
\hline 125 & $\begin{array}{l}\text { All other basic inorganic chemical manufacturing (amine addition, ammonia } \\
\text { addition, phosphate addition packages) }\end{array}$ & $\$ 76,148$ \\
\hline 186 & $\begin{array}{l}\text { Plate work and fabricated structural product manufacturing (biogas } \\
\text { emergency flare) }\end{array}$ & $\$ 28,280$ \\
\hline 188 & $\begin{array}{l}\text { Power boiler and heat exchange manufacturing (condensors, reactors, } \\
\text { reboilers, boilers) }\end{array}$ & $\$ 67,623,532$ \\
\hline 189 & Metal tank (heavy gauge) manufacturing & $\$ 49,732,808$ \\
\hline 190 & $\begin{array}{l}\text { Metal can, box, and other metal container (light gauge) manufacturing } \\
\text { (hoppers and bins) }\end{array}$ & $\$ 858,111$ \\
\hline 207 & Other industrial machinery manufacturing & $\$ 17,424,215$ \\
\hline 213 & Other commercial and service industry machinery manufacturing & $\$ 2,202,215$ \\
\hline 214 & Air purification and ventilation equipment manufacturing & $\$ 7,661,006$ \\
\hline 215 & Heating equipment (except warm air furnaces) manufacturing & $\$ 866,448$ \\
\hline 216 & $\begin{array}{l}\text { Air conditioning, refrigeration, and warm air heating equipment } \\
\text { manufacturing }\end{array}$ & $\$ 2,358,524$ \\
\hline 222 & Turbines and turbine generator set units manufacturing & $\$ 15,556,781$ \\
\hline 226 & Pump and pumping equipment manufacturing & $\$ 2,413,742$ \\
\hline 227 & Air and gas compressor manufacturing & $\$ 625,322$ \\
\hline 228 & Material handling equipment manufacturing & $\$ 15,031,399$ \\
\hline 230 & Other general purpose machinery manufacturing & $\$ 12,654,888$ \\
\hline 355 & Nondepository credit intermediation and related activities & $\$ 37,264,976$ \\
\hline 357 & Insurance carriers (prorateable expenses) & $\$ 22,332,735$ \\
\hline 360 & Real estate establishments (land) & $\$ 1,538,934$ \\
\hline 369 & Architectural, engineering, and related services & $\$ 65,598,577$ \\
\hline \multicolumn{3}{|c|}{ Annual operating } \\
\hline 19 & Support activities for agriculture/forestry & $\$ 1,092,872$ \\
\hline 33 & Water, sewage, and other systems & $\$ 297,781$ \\
\hline 44 & Wet corn milling & $\$ 9,403,026$ \\
\hline 123 & Alkalies and chlorine manufacturing & $\$ 3,035,231$ \\
\hline 125 & Other basic inorganic chemical manufacturing & $\$ 1,769,796$ \\
\hline 126 & Other basic organic chemical manufacturing & $\$ 1,451,208$ \\
\hline 130 & Phosphatic fertilizer manufacturing & $\$ 4,294,044$ \\
\hline 164 & Lime and gypsum product manufacturing & $\$ 1,248,137$ \\
\hline 326 & Retail stores/gasoline stations & $\$ 5,599,311$ \\
\hline 338 & Support activities for transportation & $\$ 4,512,713$ \\
\hline 357 & Insurance carriers & $\$ 4,109,223$ \\
\hline 390 & Waste management and remediation services & $\$ 1,339,402$ \\
\hline 414 & Auto repair/maintenance & $\$ 1,488,424$ \\
\hline 417 & Commercial machinery repair and maintenance & $\$ 4,578,444$ \\
\hline 22 & Feedstock costs (old mining iron ore) & $\$ 35,520,675$ \\
\hline 36 & $\begin{array}{l}\text { Construction of other new nonresidential structures (dome reclaim system, } \\
\text { concrete feedstock storage dome, anaerobic basin) }\end{array}$ & $\$ 3,458,975$ \\
\hline 125 & $\begin{array}{l}\text { All other basic inorganic chemical manufacturing (amine addition, ammonia } \\
\text { addition, phosphate addition packages) }\end{array}$ & $\$ 7,615$ \\
\hline 186 & $\begin{array}{l}\text { Plate work and fabricated structural product manufacturing (biogas } \\
\text { emergency flare) }\end{array}$ & $\$ 2,828$ \\
\hline
\end{tabular}


TABLe 3: Continued.

\begin{tabular}{llc}
\hline IMPLAN sector & IMPLAN sector description & 2010 transactions \\
\hline 188 & $\begin{array}{l}\text { Power boiler and heat exchange manufacturing (condensors, reactors, } \\
\text { reboilers, boilers) }\end{array}$ & $\$ 6,762,353$ \\
189 & Metal tank (heavy gauge) manufacturing & Metal can, box, and other metal container (light gauge) manufacturing \\
& (hoppers and bins) & $\$ 4,973,281$ \\
190 & Other industrial machinery manufacturing & $\$ 85,812$ \\
207 & Other commercial and service industry machinery manufacturing \\
213 & Air purification and ventilation equipment manufacturing & $\$ 1,742,422$ \\
214 & Heating equipment (except warm air furnaces) manufacturing \\
215 & Air conditioning, refrigeration, and warm air heating equipment \\
216 & manufacturing & $\$ 220,222$ \\
222 & Turbines and turbine generator set units manufacturing \\
226 & Pump and pumping equipment manufacturing & $\$ 766,100$ \\
227 & Air and gas compressor manufacturing & $\$ 235,645$ \\
228 & Material handling equipment manufacturing & $\$ 1,555,678$ \\
230 & Other general purpose machinery manufacturing & $\$ 241,375$ \\
31 & Electricity and distribution services (coproduct) & $\$ 62,532$ \\
\hline
\end{tabular}

Source: adapted from [25].

by the darker green colors in Figures 1 and 2 was higher than in other land resource units. The opportunity cost of converting pasture/hay production to switchgrass production was the least among all crops in the model. Thus, available pasture/hay lands and switchgrass biomass yield $\mathrm{ha}^{-1}$ in each land resource unit determined the density of switchgrass produced in that spatial unit. To meet annual feedstock demand of the biorefinery, a portion of switchgrass production was harvested and delivered to the biorefinery in each of the four harvest months. Remaining production was harvested and placed in storage for delivery to the biorefinery from March through October.

Switchgrass was planted on over 29,000 ha under each bale harvest and storage system scenario (Table 4). For each system, pasture/hay production was the primary land use before being converted to switchgrass production. For all four bale harvest and storage systems, $96 \%$ of total area in switchgrass production was previously in pasture/hay production. The remainder of land converted to switchgrass production was previously in wheat $(3 \%)$, soybean $(0.7 \%)$, and corn $(0.4 \%)$ production. Reduced pasture/hay production represents a loss to the economy as input purchases to produce this activity on these lands are impacted in the analysis. The reduction in pasture/hay production was modeled as a loss of rental payments.

The total plant gate cost for supplying 596,838 dry Mg of switchgrass to the biorefinery was estimated to be about $\$ 46.2$ million for the Square Top and Bottom Protected system and \$48.2 million for the Round Unprotected system assuming that the biorefinery will produce $189,271 \mathrm{kl} \mathrm{year}^{-1}$. Harvest cost accounted for $53 \%$ to $54 \%$ of the total costs in the round bale systems and $49 \%$ to $60 \%$ in the square bale systems. For the square baling systems, a large difference in planted area was found and ranged from 32,297 ha for the Square
Top and Bottom Protected system to 39,465 ha for the Square Top Unprotected system. This result illustrates the impact of storage dry matter losses on feedstock and the need to protect large square bales during storage. Transportation cost accounted for about $26 \%$ and $20 \%$ of total plant gate costs for the round and square bale systems, respectively.

Comparing the costs of each component in those two systems, the square bale system with protection during storage had lower plant gate costs than the round bale system but had higher production and storage costs. The square bale system required more switchgrass area $(811 \mathrm{ha})$ than the round bale system to meet the demand because dry matter losses during storage for square bales were larger than for round bales. However, the advantage of lower harvest and transportation costs for square bales when compared with round bales outweighed the additional production cost. However, round balers are commonly used for beef production in the study region where pasture/hay production is the dominate land activity. Thus, an additional investment would need to be made in square balers with switchgrass production. Because of the weight difference between square bales $\left(608 \mathrm{~kg} \mathrm{bale}^{-1}\right)$ and round bales $\left(336 \mathrm{~kg} \mathrm{bale}^{-1}\right)$ and that trucks loaded with square bales were closer to the allowable axle weight when compared to the round bale system, less trips to the biorefinery for square bales were required. This lowered transportation costs in the square bale system.

4.2. Economic Impacts to the Region. The estimated annual economic impact of the expenditures associated with switchgrass production, harvest, storage, transportation, and conversion to ethanol was estimated to be $\$ 301.6$ million for the Round Unprotected system (Table 5). Economic impacts for the conversion facility are determined by Annual Operating Total + Switchgrass Production Annual Operating 


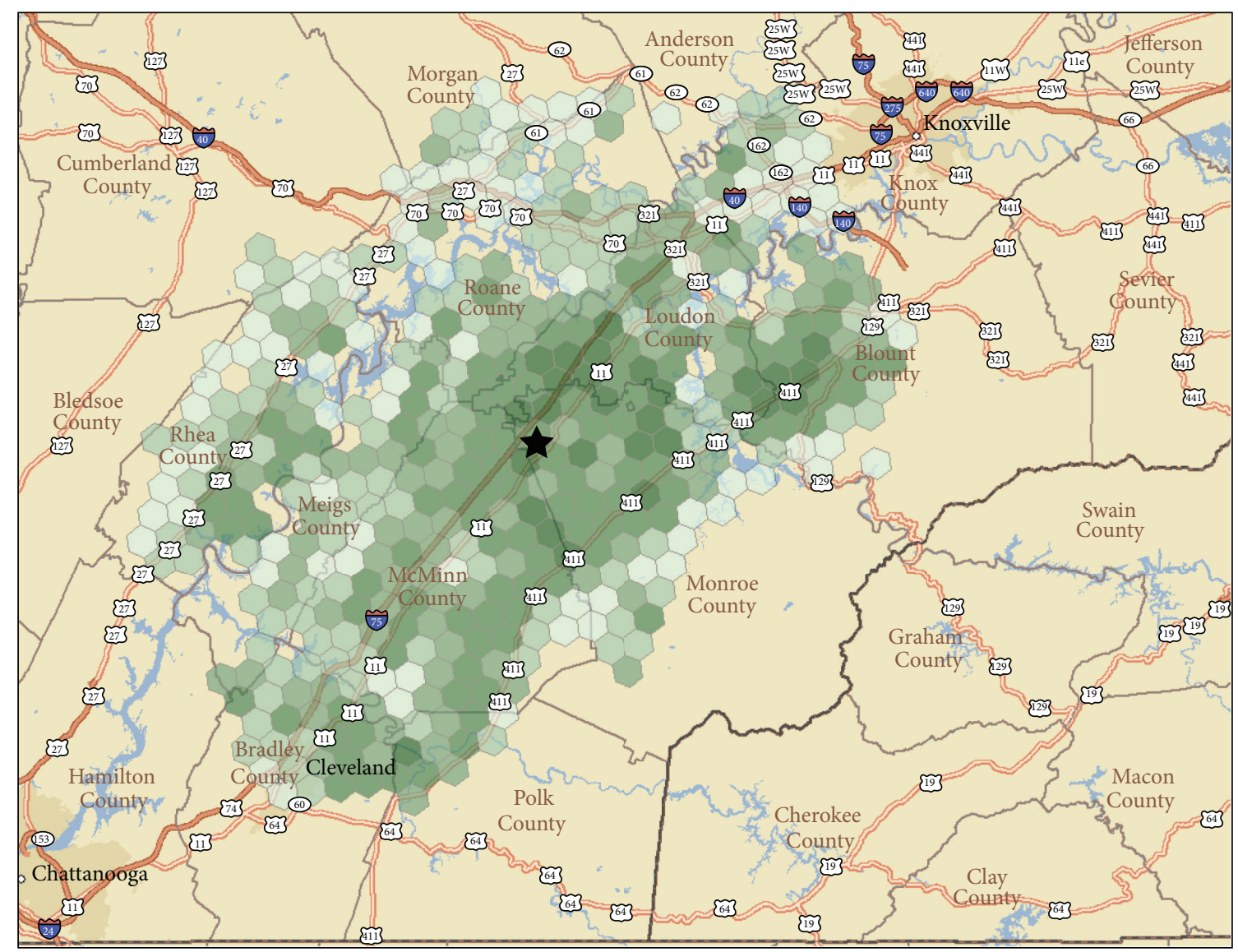

Feedstock supply round bales (tons)

$\begin{array}{ll}\square & 8-667 \\ \square & 668-1,330 \\ \square & 1,331-2,116 \\ 2,117-3,299 \\ 3,300-6,891\end{array}$

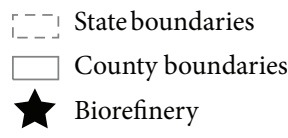

FiguRE 2: Feedstock draw area under large round bale system.
Total - Cropland Converted Total $=$ Total Impact, that is, $\$ 233,984,335+\$ 92,539,435-\$ 24,877,032=\$ 301,641,738$ using the numbers from Table 5. The NREL technology modeled requires glucose for enzyme production, and it is a significant expense for the biorefinery and has a large employment multiplier of 11 in the region. Glucose may be derived from the corn syrup manufacturer located in the region.

Other industries with an employment multiplier greater than four include fluid milk and butter manufacturing; animal (except poultry) slaughtering, rendering, and processing; flour milling and malt manufacturing; pesticide and other agricultural chemical manufacturing; federal electric utilities; sound recording industries; pharmaceutical preparation manufacturing; and alkalies and chlorine manufacturing. For this system, an estimated 673 jobs would be directly created and 1,557 jobs annually in the economy when the indirect and induced impacts were also considered. Operation of the biorefinery requires an estimated 60 jobs and assuming an ethanol price of $\$ 0.9171^{-1}$ produced nearly $\$ 170$ million in revenue (direct). Purchases of inputs required including transportation were estimated to add \$233.9 million of economic output to the region's economy. Switchgrass production, harvest, and storage activities added 927 jobs directly and 1,442 jobs within the region. However, changes in land use from switchgrass production resulted in a loss of 417 jobs linked to agriculture so the net increase in agricultural jobs was 1,025 with a net increase in economic output of \$68 million for the Round Unprotected system. Labor income was estimated to increase in the region by over $\$ 44.4$ million and Gross Domestic Product (GDP) or valueadded increased by close to $\$ 130$ million for the region annually.

By comparison, an overall impact of $\$ 302.0$ million was projected for the Square Top and Bottom Protected system. For this system, an estimated 698 jobs would be created directly and 1,584 jobs annually in the economy when indirect and induced impacts were also considered. As for the Round Unprotected system, biorefinery operations were not affected 


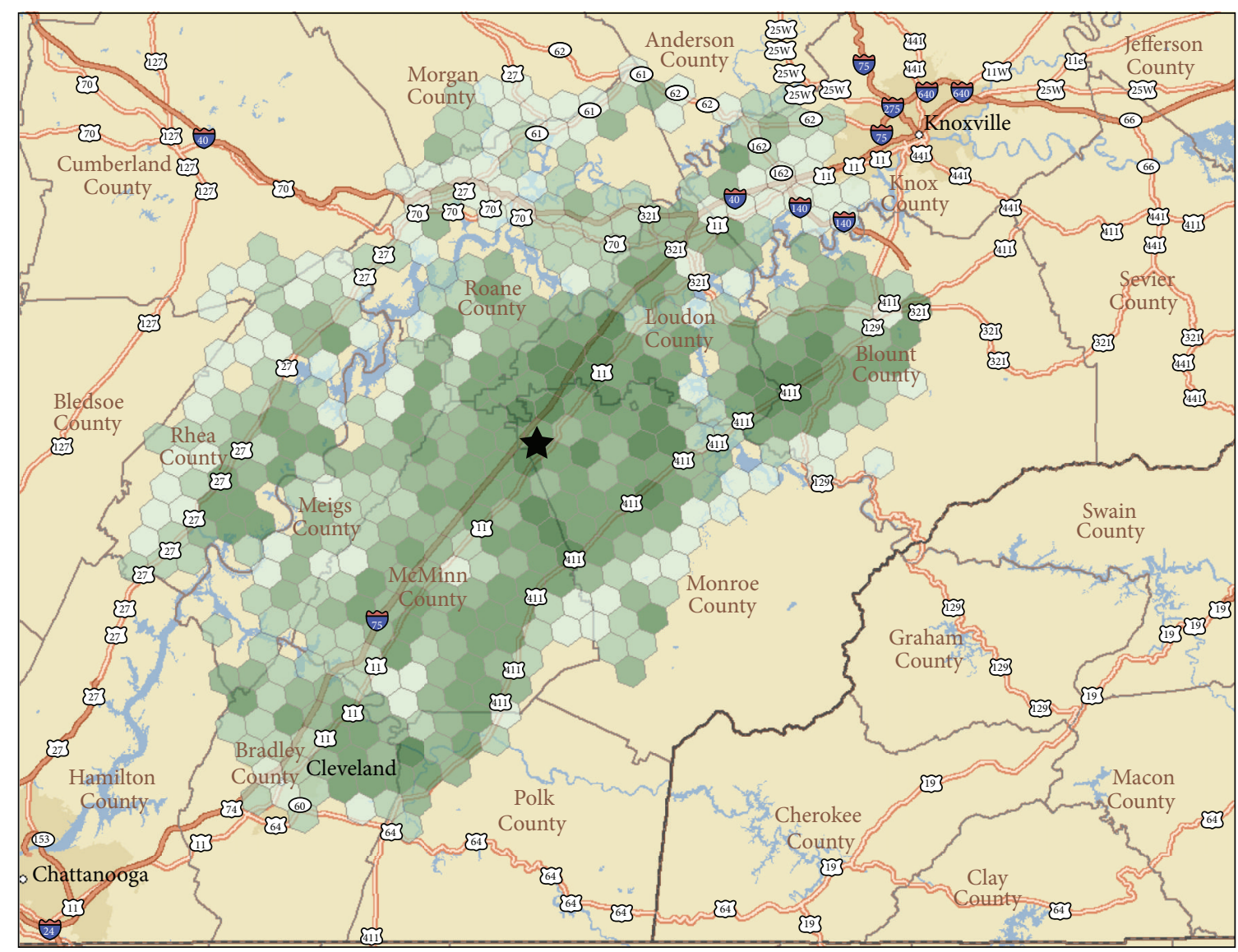

Feedstock supply square bales (tons)

\begin{tabular}{ll}
$\square-667$ & \\
$668-1,330$ & $\square$ County boundaries \\
$1,331-2,116$ & \multirow{1}{*}{ Biorefinery } \\
$2,117-3,299$ &
\end{tabular}

FIGURE 3: Feedstock draw area under large square bale system.

by the choice of feedstock delivery system and produced an estimated 60 jobs and nearly $\$ 170$ million in revenue (direct). Purchases of inputs required including transportation were estimated to add $\$ 230.1$ million of economic output to the region's economy. The production, harvest, and storage of feedstock added 951 jobs directly and 1,521 jobs within the region. However, land use changes resulted in a loss of 425 jobs linked to agriculture, so the net increase in agricultural and transportation jobs was 1,096 with a net increase in economic activity of $\$ 72$ million for the Square Top and Bottom Protected system. Labor income was estimated to increase in the region by over $\$ 44.8$ million and increase GDP or value added by over $\$ 131.6$ million annually.

As with the estimated annual economic impacts, the investment impacts for the 13-county area were similar for the different bale harvest and storage systems. The largest investment impact was for the construction of the biorefinery. For the large round bale system, total industry output from direct expenditures of $\$ 390.5$ million (\$15.9 million for the establishment of switchgrass and \$374.6 million for the construction of the biorefinery) financed nearly 2,500 jobs in the farming, trucking, and trucking support industries and created \$187.1 million in direct total value added. These transactions stimulated the input supplying industries by \$131.4 million (indirect impacts) and increased impacts from expenditures from households by $\$ 164.7$ million (induced impacts). The overall economic impact of investments made on the development of a biorefinery in East Tennessee was estimated at more than $\$ 686$ million. The estimated total number of jobs supported from the all those activities was nearly 5,000. The one-time investment created addition to GDP of $\$ 360$ million with $\$ 244$ million of that going to labor income.

\section{Conclusions}

Evaluating the economic impacts of a potential biorefinery is a key step in the assessment of the economic, environmental, 
TABLE 4: Total delivered feedstock cost for alternative harvest/storage systems.

\begin{tabular}{|c|c|c|c|c|}
\hline \multirow[b]{2}{*}{ Item and units } & \multicolumn{4}{|c|}{ Harvest/Storage System } \\
\hline & $\begin{array}{c}\text { Round: bottom } \\
\text { unprotected }\end{array}$ & Round: unprotected & $\begin{array}{l}\text { Square: top and } \\
\text { bottom protected }\end{array}$ & $\begin{array}{l}\text { Square: top } \\
\text { unprotected }\end{array}$ \\
\hline Production $^{\mathrm{a}}(\$)$ & $\$ 8,674,911$ & $\$ 8,979,650$ & $\$ 9,210,098$ & $\$ 11,247,618$ \\
\hline Harvest (\$) & $\$ 25,638,978$ & $\$ 26,541,025$ & $\$ 23,898,454$ & $\$ 29,187,083$ \\
\hline Storage $(\$)$ & $\$ 1,849,872$ & $\$ 0$ & $\$ 3,322,649$ & $\$ 2,462,736$ \\
\hline Transportation (\$) & $\$ 12,640,953$ & $\$ 12,693,320$ & $\$ 9,825,740$ & $\$ 10,102,615$ \\
\hline Total $(\$)$ & $\$ 48,804,714$ & $\$ 48,213,995$ & $\$ 46,256,941$ & $\$ 53,000,052$ \\
\hline Cost/dry ton produced (\$/Mt) & $\$ 78.52$ & $\$ 74.93$ & $\$ 70.11$ & $\$ 65.81$ \\
\hline Cost/dry ton delivered (\$/Mt) & $\$ 81.77$ & $\$ 80.78$ & $\$ 77.50$ & $\$ 88.80$ \\
\hline \multicolumn{5}{|l|}{ Cropland converted } \\
\hline Hay (hectares) & 29,084 & 30,150 & 30,938 & 38,078 \\
\hline Corn (hectares) & 121 & 121 & 121 & 121 \\
\hline Soybeans (hectares) & 227 & 231 & 255 & 261 \\
\hline Wheat (Hectares) & 982 & 983 & 983 & 1,004 \\
\hline Total (hectares) & 30,414 & 31,486 & 32,297 & 39,465 \\
\hline Total tonnage produced (Mt) & 621,550 & 643,387 & 659,862 & 805,439 \\
\hline
\end{tabular}

and social impacts of LCB-based biofuels production on a rural community. The optimal harvest and logistics system for moving LCB feedstock from the field to the biorefinery has been recognized as one crucial component to the development of a sustainable LCB-based biofuel industry. In this study, minimum plant-gate costs were evaluated for two conventional hay harvest technologies and four alternative methods of storage. A spatially-oriented, mixedinteger mathematical programming model was used to evaluate the alternative harvest and storage systems for a 13county region in East Tennessee. The economic impacts of establishing a biorefinery with an annual production capacity of $189,271 \mathrm{kl}$ of ethanol for the optimal alternative harvest and storage systems were evaluated using input-output analysis. Costs generated from the production, harvest, storage, and transportation of switchgrass plus an opportunity cost equal to the net profit generated from traditional cropping systems were considered in the analysis. Incorporated in those costs were dry matter losses based on storage method and the costs of monthly truck flows from the supply areas to the biorefinery on the regional road network. A minimum cost solution was determined and biorefinery located for each bale harvest and storage alternative.

The feedstock supply area and the location of a potential commercial-scale biorefinery in a 13-county region in East Tennessee was identified by the mathematical programming model as along Interstate 75 in northwest of Monroe County under all feedstock harvest and logistics systems evaluated. The accompanying economic impact of the expenditure on the entire system from field to plant processing was estimated through an input-output analysis covering more than 400 industries in study region. For the unprotected large round bale system, the total annual expenditures of $\$ 48.3$ million were expected to generate a total $\$ 92.5$ million in economic output within the 13 counties of East Tennessee. Moreover, an estimated \$234 million in overall economic activity impact was generated through the operation of the biorefinery. The configuration of the feedstock supply systems influenced the levels and types of economic impact of the biorefinery although differences in total economic impact generated between the large round and square bale systems were not substantial.

Land use change occurred with over 30,000 hectares of switchgrass being planted primarily on pasture/hay land. The impact of the projected land use change losses could be larger or smaller than estimated. Pasture/hay land is used by dairies and cow-calf operations in the region. Dairy production in this region is on the decline and the pastures for the most part are not intensively managed. Therefore, opportunities exist to more intensively manage the remaining pastures, maintain herd size, and increase input purchases for those pastures. These productivity and potential animal practice modifications are not incorporated in the analysis. The estimated impact of the decrease in crop and hay acreage is a loss of 417 jobs and a decrease in total industry output of nearly $\$ 25$ million. These losses are more than offset by gains in switchgrass production.

Additional jobs were created in the region. An estimated 1,025 to 1,096 jobs (many are seasonal) were added in agricultural activities. In addition, operation of the biorefinery was expected to increase 60 jobs directly, 324 jobs indirectly, while another 148 were stimulated through increased household expenditures. The indirect jobs would occur as a result of increased input requirements and the delivery of those inputs to the facility. Retail stores, gasoline stations; commercial and industrial machinery and equipment repair and 
TABLE 5: Economic impacts of investing and operating a switchgrass-based ethanol refinery by harvest system.

\begin{tabular}{|c|c|c|c|c|c|c|c|c|}
\hline \multirow{2}{*}{$\begin{array}{l}\text { Type of investment } \\
\text { and impact type }\end{array}$} & \multicolumn{4}{|c|}{ Round bale, unprotected } & \multicolumn{4}{|c|}{ Square bale, top and bottom protected } \\
\hline & Jobs & Labor income & Value added & Output & Jobs & Labor income & Value added & Output \\
\hline \multicolumn{9}{|c|}{ Conversion facility investment } \\
\hline Direct & 2,244 & $\$ 134,087,241$ & $\$ 176,901,786$ & $\$ 374,613,302$ & 2,244 & $\$ 134,087,241$ & $\$ 176,901,786$ & $\$ 374,613,302$ \\
\hline Indirect & 983 & $\$ 46,442,213$ & $\$ 71,269,620$ & $\$ 127,950,178$ & 983 & $\$ 46,442,213$ & $\$ 71,269,620$ & $\$ 127,950,178$ \\
\hline Induced & 1,408 & $\$ 51,375,476$ & $\$ 94,547,910$ & $\$ 156,267,010$ & 1,408 & $\$ 51,375,476$ & $\$ 94,547,910$ & $\$ 156,267,010$ \\
\hline Total & 4,635 & $\$ 231,904,930$ & $\$ 342,719,316$ & $\$ 658,830,490$ & 4,635 & $\$ 231,904,930$ & $\$ 342,719,316$ & $\$ 658,830,490$ \\
\hline \multicolumn{9}{|c|}{ Switchgrass establishment } \\
\hline Direct & 251 & $\$ 8,589,478$ & $\$ 10,207,536$ & $\$ 15,854,564$ & 258 & $\$ 8,835,025$ & $\$ 10,494,030$ & $\$ 16,256,868$ \\
\hline Indirect & 24 & $\$ 1,089,602$ & $\$ 1,755,764$ & $\$ 3,443,035$ & 24 & $\$ 1,116,248$ & $\$ 1,801,257$ & $\$ 3,530,278$ \\
\hline Induced & 76 & $\$ 2,765,003$ & $\$ 5,091,323$ & $\$ 8,411,910$ & 78 & $\$ 2,842,820$ & $\$ 5,234,625$ & $\$ 8,648,658$ \\
\hline Total & 351 & $\$ 12,444,083$ & $\$ 17,054,623$ & $\$ 27,709,509$ & 361 & $\$ 12,794,093$ & $\$ 17,529,912$ & $\$ 28,435,804$ \\
\hline \multicolumn{9}{|c|}{ Conversion facility annual operating } \\
\hline Direct & 60 & $\$ 4,150,897$ & $\$ 67,201,544$ & $\$ 169,912,135$ & 60 & $\$ 4,150,897$ & $\$ 69,158,596$ & $\$ 169,912,135$ \\
\hline Indirect & 324 & $\$ 14,806,660$ & $\$ 22,271,726$ & $\$ 47,650,262$ & 289 & $\$ 13,600,361$ & $\$ 20,505,583$ & $\$ 44,775,299$ \\
\hline Induced & 148 & $\$ 5,397,277$ & $\$ 9,938,523$ & $\$ 16,421,938$ & 139 & $\$ 5,052,759$ & $\$ 9,303,923$ & $\$ 15,373,700$ \\
\hline Total & 532 & $\$ 24,354,834$ & $\$ 99,411,793$ & $\$ 233,984,335$ & 488 & $\$ 22,804,017$ & $\$ 98,968,102$ & $\$ 230,061,134$ \\
\hline \multicolumn{9}{|c|}{ Switchgrass production annual operating } \\
\hline Direct & 927 & $\$ 7,229,864$ & $\$ 12,819,955$ & $\$ 48,340,630$ & 951 & $\$ 7,416,086$ & $\$ 13,149,472$ & $\$ 49,580,673$ \\
\hline Indirect & 361 & $\$ 12,560,785$ & $\$ 17,416,003$ & $\$ 27,091,319$ & 402 & $\$ 14,125,332$ & $\$ 19,199,758$ & $\$ 29,663,678$ \\
\hline Induced & 154 & $\$ 5,623,153$ & $\$ 10,351,628$ & $\$ 17,107,486$ & 168 & $\$ 6,117,413$ & $\$ 11,260,785$ & $\$ 18,610,907$ \\
\hline Total & 1,442 & $\$ 25,413,802$ & $\$ 40,587,586$ & $\$ 92,539,435$ & 1,521 & $\$ 27,658,831$ & $\$ 43,610,015$ & $\$ 97,855,258$ \\
\hline \multicolumn{9}{|l|}{ Cropland converted } \\
\hline Direct & $(314)$ & $-\$ 1,733,939$ & $-\$ 3,970,936$ & $-\$ 13,764,754$ & (313) & $-\$ 1,717,907$ & $-\$ 3,938,061$ & $-\$ 14,116,522$ \\
\hline Indirect & $(71)$ & $-\$ 2,435,781$ & $-\$ 4,405,345$ & $-\$ 7,503,559$ & $(78)$ & $-\$ 2,662,111$ & $-\$ 4,698,499$ & $-\$ 7,960,489$ \\
\hline Induced & $(33)$ & $-\$ 1,186,188$ & $-\$ 2,183,805$ & $-\$ 3,608,719$ & $(34)$ & $-\$ 1,248,487$ & $-\$ 2,298,195$ & $-\$ 3,797,822$ \\
\hline Total & $(417)$ & $-\$ 5,355,908$ & $-\$ 10,560,086$ & $-\$ 24,877,032$ & $(425)$ & $-\$ 5,628,505$ & $-\$ 10,934,755$ & $-\$ 25,874,833$ \\
\hline
\end{tabular}

maintenance; construction of other new nonresidential structures, automotive repair and maintenance, except car washes; food services and drinking places; scenic and sightseeing transportation and support activities for transportation; real estate establishments; support activities for agriculture and forestry, and the wholesale trade businesses were the largest sectors impacted in either analysis as a result of operations in the biorefinery.

One-time investment impacts would also occur to the region. These impacts would likely be spread over several years as the facility was constructed and fields of switchgrass were planted. These impacts totaled nearly $\$ 690$ million in added economic activity from an investment of $\$ 390$ million. Jobs added to the economy during the time frame of investment would total nearly 5,000.

There are limitations to this analysis. First, cost estimates used to model the cellulosic ethanol facility will likely change as the industry develops. Second, the total net effect of the ethanol facility on the 13-region economy is difficult to capture. For example, employee movement from one industry to another is difficult to model. In addition, this facility may purchase inputs outside the region in larger proportions than modeled. Also, the transfer of engineering economic expenditures of the facility and corresponding switchgrass budgets into IMPLAN is subjective and alternative industry assignments would yield somewhat different estimates.

For future research, the modeling approach used in this paper can be extended to evaluate other harvest and logistics systems that may increase hauling efficiency and lower plant gate costs. The impacts of moving and utilizing the output of the plant could also be incorporated into the analysis. Alternative size plants and their impacts on the region might also be evaluated. Finally, this analytical framework can be applied to other energy crops or feedstock in different regions to evaluate the economic impact of the feedstock flows resulting from the emerging cellulosic bioenergy industry.

\section{References}

[1] U.S. Congress, "Energy Independence and Security Act of 2007," Public Law No: 110-140. December 19, 2007.

[2] U.S. Department of Energy, "U.S. Billion-Ton Update: Biomass Supply for a Bioenergy and Bioproducts Industry," R. D. Perlack and B. J. Stokes (Leads), ORNL/TM-2011/224, Oak Ridge National Laboratory, Oak Ridge, Tenn, USA, 227p, 2011.

[3] B. C. English, D. De La Torre Ugarte, K. Jensen et al., 25\% Renewable Energy For the United States By 2025: Agricultural and Economic Impacts, The University of Tennessee, Institute 
of Agriculture, Department of Agricultural and Resource Economics, 2006.

[4] Biomass Research and Development Technical Advisory Committee, Roadmap for Bioenergy and Biobased Products in the United States, Department of Agriculture, Washington, DC, USA, 2007, http://wwwl.eere.energy.gov/biomass/pdfs/ obp_roadmapv2_web.pdf.

[5] L. Wright, Historical Perspective on How and Why Switchgrass was Selected as a "Model" High-Potential Energy Crop, ORNL/TM-2007/109, Oak Ridge National Laboratory, Oak Ridge, Tenn, USA, 2007.

[6] L. Rinehart, Switchgrass as a Bioenergy Crop, National Center for Appropriate Technology, 2006, https://attra.ncat.org/ publication.html.

[7] S. B. McLaughlin, J. Bouton, D. Bransby et al., "Developing switchgrass as a bioenergy crop," in Perspectives on New Crops and New Uses, J. Janick, Ed., ASHS Press, Alexandria, VA, USA, 1999.

[8] S. B. McLaughlin and L. A. Kszos, "Development of switchgrass (Panicum virgatum) as a bioenergy feedstock in the United States," Biomass and Bioenergy, vol. 28, no. 6, pp. 515-535, 2005.

[9] J. A. Larson, T. Yu, B. C. English, D. F. Mooney, and C. Wang, "Cost evaluation of alternative switchgrass producing, harvesting, storing, and transporting systems and their logistics in the southeastern US," Agricultural Finance Review, vol. 70, no. 2, pp. 184-200, 2010.

[10] L. Brass, East Tennessee Farmers' First Switchgrass; Harvest Ready to Turn Into Biofuel, Checkbiotech, 2011, http://bioenergy .checkbiotech.org/news/east_tenn_farmers_first_switchgrass_ harvest_ready_turn_biofuel.

[11] D. F. Mooney, J. A. Larson, B. C. English, and D. D. Tyler, "Effects of dry matter loss on profitability of outdoor storage of switchgrass," Biomass and Bioenergy, vol. 44, pp. 33-41, 2012.

[12] W. F. Lazarus, D. G. Tiffany, R. S. Zalesny, and D. E. Riemenschneider, "Economic impacts of short-rotation woody crops for energy or oriented strand board: a Minnesota case study," Journal of Forestry, vol. 109, no. 3, pp. 149-156, 2011.

[13] P. J. Thomassin and L. Baker, "Macroeconomic impact of establishing a large-scale fuel ethanol plant on the Canadian economy," Canadian Journal of Agricultural Economics, vol. 48, no. 1, pp. 67-85, 2000.

[14] J. Miranowski, D. Swenson, L. Eathington, and A. Rosburg, "Biofuel, the rural economy, and farm structure," in Risk, Infrastructure and Industry Evolution, B. C. English, R. J. Menard, and K. Jensen, Eds., Farm Foundation Press, Washington, DC, USA, 2008.

[15] K. Mukhopadhyay and P. J. Thomassin, "Macroeconomic effects of the Ethanol Biofuel Sector in Canada," Biomass and Bioenergy, vol. 35, no. 7, pp. 2822-2838, 2011.

[16] S. J. Vogel, K. Hanson, J. M. Price, and G. Schluter, "Putting bounds on estimating economywide impacts from adopting the renewable fuels standard," AgBioForum, vol. 5, no. 3, pp. 101-104, 2002.

[17] D. De La Torre Ugarte, B. English, K. Jensen, C. Hellwinckel, J. Menard, and B. Wilson, Economic and Agricultural Impacts of Ethanol and Biodiesel Expansion, University of Tennessee, Department of Agricultural and Resource Economics, 2006, http://beag.ag.utk.edu/pub/Ethanolagimpacts.pdf.

[18] D. Swenson, "Appendix I: Biofuel Industry Economic Impacts and Analysis, in Renewable Fuels Roadmap and Sustainable Biomass Feedstock Supply for New York," 2011 Update to the
Final Report, prepared by Wojnar, October 2011, http://www .nyserda.ny.gov/Publications/Research-and-Development-Technical-Reports/Biomass-Solar-Wind-Reports/Renewable-FuelsRoadmap.aspx?sc_database=web.

[19] C. Hart, D. Otto, and M. Hudak, "Economic Impacts of the Ethanol Industry in Iowa and the U.S. Research Report, Community Vitality Center," May 2012, http://www.cvcia.org/ files/CVC-Ethanol-Report-8-9-2012.pdf.

[20] J. L. Outlaw and J. W. Richardson, "Economic impact of the current and potential biodiesel industry in Texas," Tech. Rep., Biodiesel Coalition of Texas, 2008, http://biodieselcoalitionoftexas.org/documents/TAMU\%20AFPC\%20Biodiesel\%20Economic\%20Impact\%20Study.pdf.

[21] F. L. Leistritz and N. M. Hodur, "Biofuels: a major rural economic development opportunity," Biofuels, Bioproducts and Biorefining, vol. 2, no. 6, pp. 501-504, 2008.

[22] C. Bailey, J. F. Dyer, and L. Teeter, "Assessing the rural development potential of lignocellulosic biofuels in Alabama," Biomass and Bioenergy, vol. 35, no. 4, pp. 1408-1417, 2011.

[23] B. Aksoy, H. Cullinan, D. Webster et al., "Woody biomass and mill waste utilization opportunities in Alabama: transportation cost minimization, optimum facility location, economic feasibility, and impact," Environmental Progress and Sustainable Energy, vol. 30, pp. 720-732, 2011.

[24] Y. Gao, Evaluation of pre-processing and storage options in biomass supply logistics: a case study in East Tennessee [M.S. thesis], The University of Tennessee, Knoxville, Tenn, USA, 2011.

[25] B. S. Wilson, Modeling cellulosic ethanol plant location using GIS [M.S. thesis], The University of Tennessee, Knoxville, Tenn, USA, 2009.

[26] M. Wang, C. Saricks, and D. Santini, Effects of Fuel Ethanol Use on Fuel-Cycle Energy and Greenhouse Gas Emissions, U.S. Department of Energy, Argonne National Laboratory, Center for Transportation Research, Argonne, IL, USA, 1999.

[27] G. Tembo, F. M. Epplin, and R. L. Huhnke, "Integrative investment appraisal of a lignocellulosic biomass-to-ethanol industry," Journal of Agricultural and Resource Economics, vol. 28, no. 3, pp. 611-633, 2003.

[28] D. Olson and S. Lindall, IMPLAN Professional Software, Analysis, and Data Guide, Minnesota IMPLAN Group, Hudson, WI, USA, 1999.

[29] D. Humbird, R. Davis, L. Tao et al., "Process design economics for biochemical conversion of lignocellulosic biomass to Ethanol," Tech. Rep. TP-5100-44764, NREL, 2011.

[30] J. Menard, B. C. English, and K. Jensen, Economic Impacts of Agricultural and Forestry in Tennessee, Department of Agricultural Economics, University of Tennessee, 2011, http://aimag.ag .utk.edu/pubs/ei09/ReportText.pdf.

[31] UT Extension, "Guideline Switchgrass Establishment and Annual Production Budgets 10 over Three Year Planning Horizon," University of Tennessee, Institute of Agriculture, Department of Agricultural \& Resource Economics, AE10-02, 2009, http:// biodieselcoalitionoftexas.org/documents/TAMU\% 20AFPC\%20Biodiesel\%20Economic\%20Impact\%20Study.pdf. 

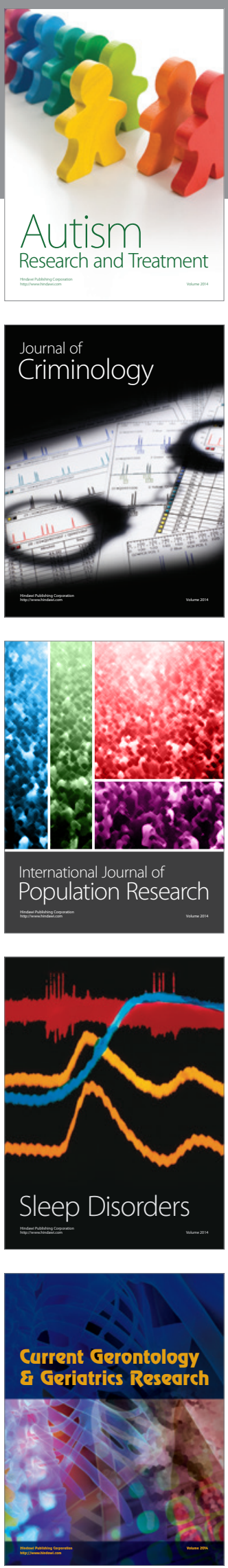
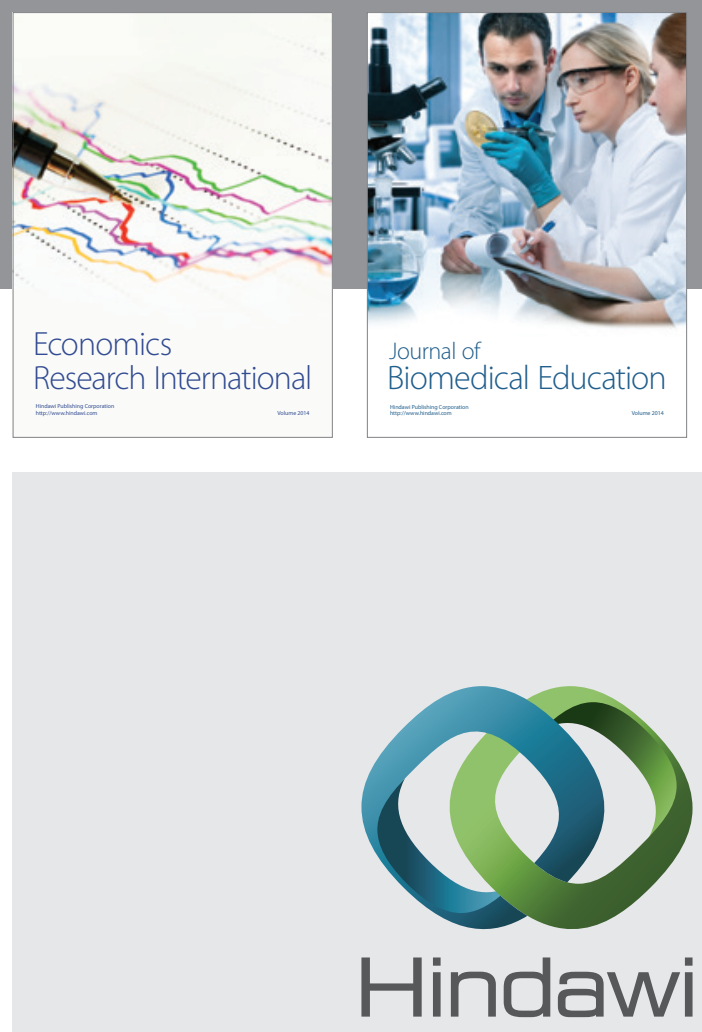

Submit your manuscripts at

http://www.hindawi.com
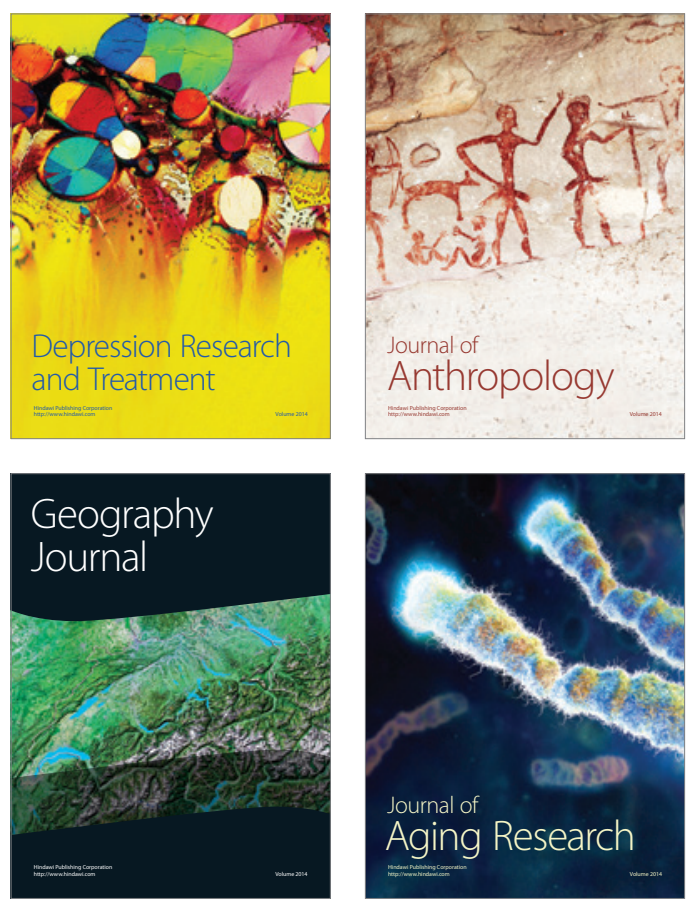
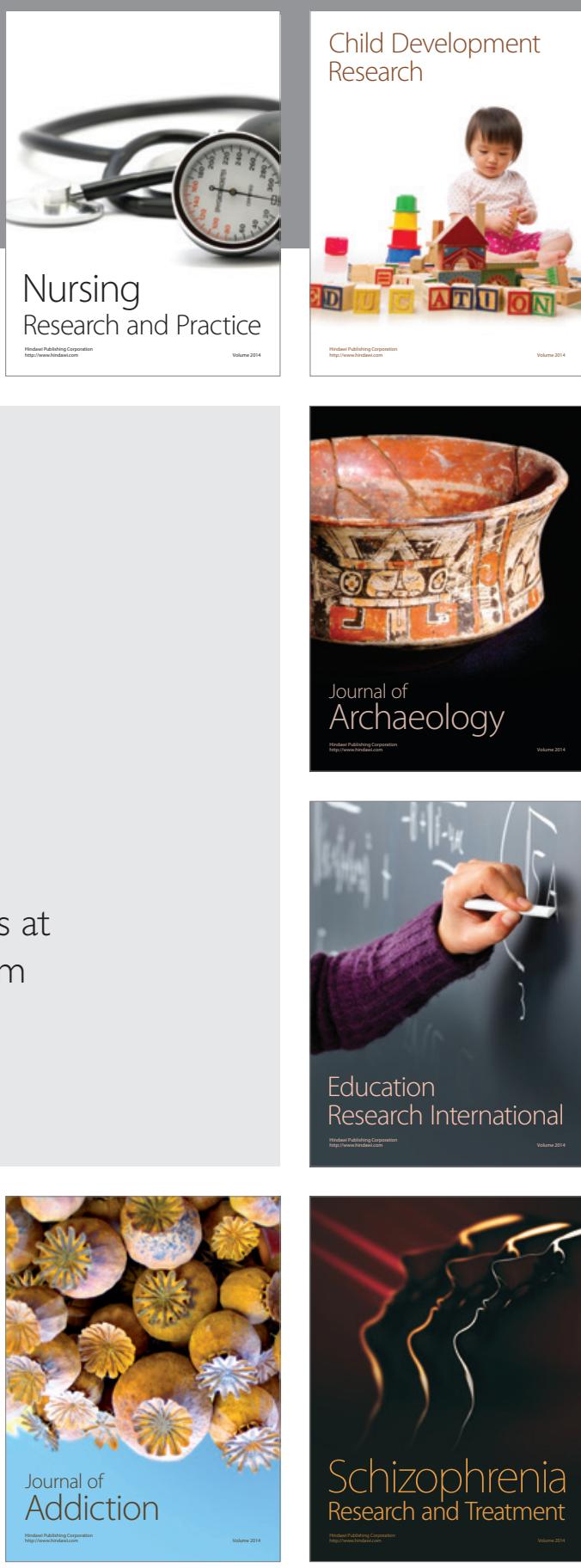

(D)
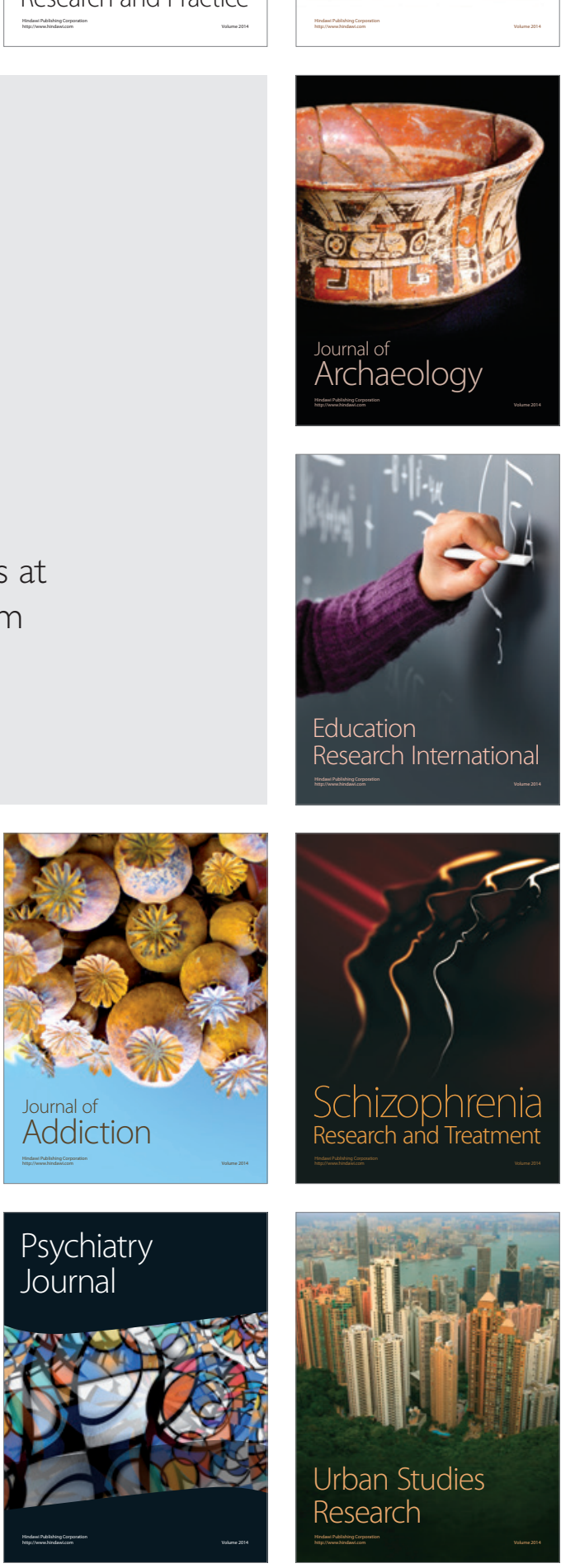